\title{
Эффективность финансового сектора как важнейшее условие обеспечения экономической безопасности государства
}

\author{
1) Гаджиев Н.Г., ${ }^{2)}$ Коноваленко С.А., ${ }^{2)}$ Корнилович Р.А., ${ }^{2)}$ Трофимов М.Н. \\ 1) Дагестанский государственный университет \\ Россия, 367000, г. Махачкала, ул. М. Гаджиева, 43a \\ nazirhan55@mail.ru \\ 2) Рязанский филиал Московского университета МВД России им. В.Я. Кикотя \\ Россия, 390043, г. Рязань, 1-я Красная ул., 18 \\ sergejkonovalenko26@gmail.com
}

\begin{abstract}
Аннотация. Обеспечение эффективности финансового сектора государства - основа формирования эффективного экономического роста и устойчивости платежной системы в Российской Федерации. Эффективность финансового сектора - это приоритетные стратегические направления в деятельности финансовых органов государственной власти, кредитного, страхового сегмента финансового рынка, направленной на формирование условий для экономического роста и финансовой стабильности при сохранении надежности финансовой системы страны. Эффективность финансового сектора страны должна обеспечиваться не только регулятивными действиями Банка России, но и всеми участниками финансового рынка в отдельности путем соблюдения утвержденных предписаний, правил и требований, регулирующих финансовые и денежно-кредитные отношения в обществе. В связи с этим требуется изучение путей повышения эффективности финансового сектора экономики России как важнейшего условия обеспечения экономической безопасности. Целью научной статьи явилось изучение роли финансового сектора на обеспечение экономической безопасности государства. Теоретической и методологической основой исследования явились работы как российских, так и зарубежных специалистов в области экономической безопасности государства, а также материалы периодической печати ведущих ученых экономистов. Основными методами исследования, использованными при написании работы, явились метод теоретического системного экономического анализа, монографический (описательный) метод.
\end{abstract}

Ключевые слова: финансовый сектор, денежно-кредитная политика, национальная платежная система, экономическая безопасность.

Для цитирования: Гаджиев Н.Г., Коноваленко С.А., Корнилович Р.А., Трофимов М.Н. 2021. Эффективность финансового сектора как важнейшее условие обеспечения экономической безопасности государства. Экономика. Информатика, 48 (2): 307-318. DOI 10.52575/2687-0932-202148-2-307-318.

\section{Efficiency of the financial sector as the most important condition for ensuring the economic security of the state}

\author{
1) Nasirkhan G. Gadzhiev, ${ }^{2)}$ Sergey A. Konovalenko, ${ }^{2)}$ Ruslan A. Kornilovich, \\ 2) Mikhail N. Trofimov \\ ${ }^{1)}$ Dagestan State University; 43a M. Gadzhieva St, Makhachkala, 367000, Russia \\ nazirhan55@mail.ru \\ ${ }^{2)}$ Ryazan branch of the Moscow University of the Ministry of Internal Affairs of Russia named after \\ V.Ya. Kikot; 18 1-ya Krasnaya St, Ryazan, 390043, Russia \\ sergejkonovalenko26@gmail.com
}

Abstract. Ensuring the efficiency of the financial sector of the state is the basis for the formation of effective economic growth and stability of the payment system in the Russian Federation. The efficiency of the financial 
sector is a priority strategic direction in the activities of the financial authorities, the credit and insurance segment of the financial market, aimed at creating conditions for economic growth and financial stability while maintaining the reliability of the country's financial system. The effectiveness of the country's financial sector should be ensured not only by the regulatory actions of the Bank of Russia, but also by all financial market participants individually by complying with the approved regulations, rules and requirements governing financial and monetary relations in the company. In this regard, it is necessary to study ways to improve the efficiency of the financial sector of the Russian economy as the most important condition for ensuring economic security. The purpose of the scientific article was to study the role of the financial sector in ensuring the economic security of the state. The theoretical and methodological basis of the study was the work of both Russian and foreign experts in the field of economic security of the state, as well as the materials of the periodical press of leading economic scientists. The main research methods used in writing the work were the method of theoretical system economic analysis, the monographic (descriptive) method.

Keywords: financial sector, monetary policy, national payment system, economic security.

For citation: Gadzhiev N.G., Konovalenko S.A., Kornilovich R.A., Trofimov M.N. 2021. Efficiency of the financial sector as the most important condition for ensuring the economic security of the state. Economics. Information technologies, 48 (2): 307-318. DOI 10.52575/2687-0932-2021-48-2-307-318.

\section{Введение}

Эффективность финансового сектора может быть увеличена за счет реализации Стратегии повышения финансовой доступности в Российской Федерации на период 20182020 годов (одобрена Советом директоров Банка России 26.03.2018). В соответствии с решением Совета директоров Банка России от 23 октября 2020 года действие документа было продлено на весь 2021 год. Основа стратегии - цифровая финансовая инфраструктура, которая предполагает формирование и развитие следующих ключевых ее элементов:

○ платформа-маркетплейс для финансовых услуг и регистрации финансовых сделок обеспечат возможность получения услуг клиентами в режиме «единого окна»;

○ платформа мгновенных платежей обеспечит возможность проведения онлайнпереводов на финансовом рынке в режиме реального времени (например, номера мобильного телефона, QR-кода) и др.;

○ единая система идентификации и аутентификации и единая биометрическая система для обеспечения возможности дистанционного оказания финансовых услуг.

Формирование и развитие единой цифровой финансовой инфраструктуры будет способствовать повышению доступности и качества финансовых услуг для всех заинтересованных пользователей [Коноваленко и др., 2019].

Формирование положительных тенденций экономического роста существенно зависит от ресурсной составляющей финансовой сферы - возможностей содействовать этому, а также противодействовать различного рода отрицательным внешним воздействиям.

Финансовый сектор экономики относится к институциональным секторам экономики. Институциональный сектор экономики - это группа институциональных единиц (хозяйствующих субъектов), которая может от своего имени владеть активами, осуществлять экономические операции с другими единицами на основании однородности с точки зрения выполняемых ими функций в экономическом процессе [Коноваленко и др., 2021].

Финансовый сектор экономики непосредственно связан со всей системой экономической безопасности государства, так как обеспечивает возможность накачки экономической системы государства денежными средствами и финансовыми ресурсами в объеме, необходимом для устойчивого экономического роста и финансовой устойчивости государства.

Таким образом, эффективность финансового сектора - важнейшее условие обеспечения экономической безопасности государства. 
Финансовый сектор экономики включается в институциональный сектор экономики и включает в себя: (1) кредитные учреждения; (2) страховые учреждения; (3) инвестиционные фонды; (4) управляющие компании и пайщиков паевых инвестиционных фондов (ПИФов); (5) профессиональных участников рынка ценных бумаг [Седова, 2016].

К кредитным учреждениям относятся: коммерческие банки и небанковские кредитные организации.

Кредитные учреждения обеспечивают оборачиваемость ликвидности в экономике, аккумуляцию сбережений и инвестиций в реальный сектор экономики страны, создают условия для обеспечения положительного денежного потока в рамках производственной и финансовой деятельности субъектов хозяйствования.

Страховые учреждения - государственные и частные компании, занимающиеся всеми видами страхования. Финансирование издержек происходит за счет страховых премий. бумаги.

Инвестиционные фонды являются основой инвестирования имущества в ценные

Паевые инвестиционные фонды - обособленные имущественные комплексы, которые состоят из имущества, переданного в доверительное управление управляющим компаниям [Костыря, Трофимов, 2012].

В основе устойчивого социально-экономического развития лежит принцип роста капитальных инвестиций. Согласно оценкам Минэкономразвития России, рост прямых капитальных инвестиций на $1 \%$ обеспечивает в настоящий момент увеличение ВВП на $0,3-$ $0,4 \%$. По-прежнему большая часть инвестиционных вложений производится за счет собственных финансовых средств предприятий, что свидетельствует о недостаточной эффективности банковской системы РФ [Чайка, 2015]. Прочие источники инвестиций занимают незначительную долю в общем объеме инвестиций. Сложившаяся ситуация требует развитие механизма частно-государственного партнерства в финансовой сфере.

\section{Объекты и методы исследования}

Объектом исследования выступает состояние финансового сектора экономики страны как составной части системы экономической безопасности государства.

Основными методами при проведении научного исследования явились: метод группировки данных; монографический метод; обобщения и анализа результатов.

Метод теоретического системного экономического анализа, применялся в отношении исследования основных показателей эффективности финансового сектора экономики страны и оценки динамики преступлений в финансовой сфере по данным МВД России.

Метод группировки данных применялся при оценке эффективности банковской системы и национальной платежной системы.

Монографический метод использовался на всех этапах научного исследования.

\section{Результаты и их обсуждение}

Нынешнее положение в финансовом секторе связано как с низкой эффективностью финансовой сферы, так и с сохранением энергосырьевой направленности экспорта, на развитие финансового сектора оказывает влияние ряд факторов, прежде всего это низкая защищенность кредиторов в сфере микрофинансового кредитования, значительный рост мошенничеств в кредитно-финансовой сфере, значительный разрыв в процентных ставках по депозитам и кредитным продуктам, медленное развитие цифровизации финансового рынка и недоверия к рынку ценных бумаг клиентов, создание искусственных барьеров для развития механизма венчурного софинансирования проектов на финансовых площадках.

Страны с сырьевой ориентацией экспорта получают существенные проблемы в системе работы финансового сектора, так как значительная экспортная выручка оказывает давление на совокупный спрос и увеличение расходной части бюджета, в свою очередь это отражается на повышения курса национальной валюты, возникают диспропорции в развитии 
производственного, торгового и финансового сектора экономики («голландская болезнь») [Reutov, 2019]. Все это в конечном счете влечет за собой следующие проблемы:

- у населения формируется ложное представление о ситуации, складывающейся в стране, при этом производственная и технологическая составляющие экономики деградируют, так как все инвестиции поступают в экспортно-ориентированный сектор экономики;

- избыток средств приводит к оттоку капитала из страны (приобретению собственности за границей правящей элитой, росту туристических потоков, излишним и нередко неэффективным государственным расходам, и постепенному увеличению дефицита бюджета);

- утрачиваются стимулы к развитию экономики со стороны всех субъектов экономических отношений.

Особое значение для безопасности финансового сектора играют резервы и стабилизационные фонды.

В 2008 г. оказалось, что Стабилизационный фонд выполнил свои задачи, поэтому впоследствии он был трансформирован в Резервный фонд и Фонд национального благосостояния [Моторина, 2017].

Важность Резервного фонда и Фонда национального благосостояния для национальной экономики огромна, так, средства, накопленные в них, позволяют сбалансировать федеральный бюджет в результате непредвиденных расходов и чрезвычайных ситуаций, сформировать тренд развития приоритетных направлений в экономике в зависимости от стратегических целей государства.

Предпосылкой формирования фондов в Российской Федерации стала высокая зависимость экономики страны от экспортных цен на топливно-энергетические ресурсы. В Федеральном законе от 02.12.2019 № 380-Ф3 «О федеральном бюджете на 2020 год и на плановый период 2021 и 2022 годов» отмечается, что объем Фонда национального благосостояния (ФНБ) в 2020 г. составит 8172 трлн руб., в 2021 г. - 11 059,5 трлн руб., в 2022 г. 13658,0 трлн руб., или около 10,6 \% к ВВП страны (табл. 1.) ${ }^{1}$.

Таблица 1

Table 1

Фонд национального благосостояния в 2019-2022 гг. (млрд руб.)

The national welfare Fund in the years 2019-2022 (bln rub.)

\begin{tabular}{|l|c|c|c|c|}
\hline Показатель & 2019 г. & 2020 г. & 2021 г. & 2022 г. \\
\hline Объем ФНБ на начало года & 4036,0 & 8172,0 & 11059,5 & 13658,0 \\
\hline \% ВВП & 3,7 & 7,2 & 9,2 & 10,6 \\
\hline $\begin{array}{l}\text { остатки средств на счетах по учету средств ФНБ } \\
\text { в Банке России }\end{array}$ & 2355,6 & 6546,7 & 9570,7 & 12165,0 \\
\hline \% ВВП & 2,2 & 5,8 & 8,0 & 9,5 \\
\hline иные финансовые активы & 1680,4 & 1625,3 & 1488,8 & 1493,0 \\
\hline \% ВВП & 1,6 & 1,4 & 1,2 & 1,2 \\
\hline Объем ФНБ на конец года & 8172,0 & 11059,5 & 13658,0 & 16196,3 \\
\hline \% ВВП & 7,5 & 9,8 & 11,3 & 12,6 \\
\hline $\begin{array}{l}\text { остатки средств на счетах по учету средств ФНБ } \\
\text { в Банке России }\end{array}$ & 6546,7 & 9570,7 & 12165,0 & 14715,5 \\
\hline \% ВВП & 6,0 & 8,5 & 10,1 & 11,5 \\
\hline иные финансовые активы & 1625,3 & 1488,8 & 1493,0 & 1480,8 \\
\hline \% ВВП & 1,5 & 1,3 & 1,2 & 1,2 \\
\hline
\end{tabular}

${ }^{1}$ О федеральном бюджете на 2020 год и на плановый период 2021 и 2022 годов: федер. закон от 02.12.2019 № 380-Ф3 // Официальный интернет-портал правовой информации. URL: http://publication.pravo.gov.ru/Document/View/0001201912030041 (дата обращения: 20.12.2019). 
Проблема повышения эффективности финансовой сферы в рамках обеспечения экономической безопасности предполагает решение Правительством РФ следующих задач:

1) проведение эффективной денежно-кредитной политики,

2) санирование банковской системы

3) развитие финансовых рынков и новых форм финансовых инструментов.

Эффективность денежно-кредитной политики. В современной экономической теории денежно-кредитная, или монетарная, политика - доминирующая экономическая политика большинства государств мира. Сущность ее заключается в поддержании соответствия денежной массы и стоимостного значения объемов производства (номинального ВВП страны). Для обеспечения экономического роста достаточно создать небольшое превышение объема денежной массы над объемами производства, что подстегнет рынок к дополнительному росту потребления за счет более привлекательных цен на товары, работы в услуги. Вместе тем денежно-кредитная политика не может быть эффективной без применения точечных настроек макроэкономических параметров и правильного сочетания применяемых инструментов регулирования денежной массы в экономике [Долбилов, Лошаков, 2017].

Существенным и приоритетным инструментом денежно-кредитной политики считается регулирование процентных ставок Банком России (направленных на таргетирование инфляционных процессов), так и стимулирования роста ВВП (посредством политики «дешевых денег», снижения процентных ставок по банковским кредитам предприятиям одновременно с увеличением объема кредитования). Регулятивные функции учетных ставок можно сравнить с штурвалом корабля, действия Банка России в этой сфере создают направляющее воздействие для всего финансового сектора. Снижение ставок становится сигналом к импульсу повышения инвестиционной активности. Повышение ставок ориентирует всех участников финансового рынка на переориентацию применения в своей деловой политики финансовых инструментов и сворачивании наименее рентабельных проектов.

Значение процентных ставок в экономике сводится к следующим функциям:

- они должны отражать реальную стоимость свободных денежных средств в экономике, обеспечивая возможность аккумулирования денежных средств в наиболее рентабельных производствах, активизируя мультипликационный эффект в экономике;

- их уровень должен оказывать стимулирующее воздействие на инвестиционную активность;

- они одновременно с динамикой обменного курса рубля (и уровнем различного рода рисков) определяют стоимость внешних заимствований;

- их используют в качестве основного инструмента денежного регулирования (инструмента «мягкого» давления на финансовый рынок) [Vivchar, 2016].

Уровень процентных ставок в российской экономике существенно различается в зависимости от вида финансовых инструментов. Это связано с рейтингом финансовых инструментов и рисковой составляющей финансовых инструментов [Гаджиев и др., 2019].

Еще одним важным аспектом, определяющим денежную политику, является распределение свободных средств в экономике. Основная проблема здесь - процесс размещения свободного избытка денежных средств в реальный сектор экономики. Так, банки предпочитают использовать их для спекулятивных валютных и финансовых операций (средства размещаются в менее рисковые финансовые инструменты государства или выводятся в офшоры для последующего приобретения активов за рубежом) вместо того, чтобы направлять средства на кредиты и займы отечественному производителю. Со стороны мегарегулятора должны приниматься меры для пресечения таких действий [Коноваленко, Трофимов, 2019].

Эффективность банковской системы и национальной платежной системы. Банковская система традиционно сравнивается с кровеносной системой человека; через банковскую систему реализуются функции инвестирования, накопления, сбережения и кредитования экономики. 

категории:

Основные функции банковской системы могут быть разделены на следующие

- предоставление экономике банковских услуг (лизинг, кредитование, факторинг, страхование, поручительство и т. д.);

- аккумулирование сбережений и накоплений общества;

- осуществление посреднической финансовой деятельности.

Банки в 2017-2020 гг. недостаточно активно занимались кредитованием бизнеса. Проблемы прежние: высокий уровень просрочки в сегменте (15\% против $7 \%$ в корпоративном кредитовании), высокие риски. При этом активно развивался лизинг, прирост которого составил $50 \%$ в структуре лизингового бизнеса. [Авдийский и др., 2015] Представляется, что в 2021 г. данная тенденция сохранится, лизинг будет пользоваться спросом и, скорее всего, также продемонстрирует активную динамику.

В табл. 2 приведены условия предоставления финансовых услуг - кредита и лизинга.

Таблица 2

Table 2

Сравнение кредита и лизинга

Comparison of credit and leasing

\begin{tabular}{|c|c|}
\hline Кредит & Лизинг \\
\hline $\begin{array}{l}\text { Годовая стоимость кредита определяется как } \\
\text { произведение годовой процентной ставки и } \\
\text { остатка долга }\end{array}$ & $\begin{array}{l}\text { Годовая стоимость лизинга }- \text { удорожание } \\
\text { приобретаемого имущества за год }\end{array}$ \\
\hline $\begin{array}{l}\text { Проценты по кредиту и комиссия банку в учете } \\
\text { относятся на расходы компании; погашение } \\
\text { кредита не относится на расходы }\end{array}$ & $\begin{array}{l}\text { Лизинговые платежи относятся на расходы } \\
\text { компании }\end{array}$ \\
\hline $\begin{array}{l}\text { Имущество, приобретенное в кредит, - } \\
\text { собственность компании, оно ставится на баланс }\end{array}$ & $\begin{array}{l}\text { Имущество, взятое в лизинг, может быть на } \\
\text { балансе как лизингополучателя, так и лизинговой } \\
\text { компании }\end{array}$ \\
\hline $\begin{array}{l}\text { НДС возмещается в полном объеме от стоимости } \\
\text { приобретаемого в к кредит имущества в } \\
\text { следующем периоде после приобретения }\end{array}$ & $\begin{array}{l}\text { НДС возмещают постепенно на протяжении всего } \\
\text { периода лизинга }\end{array}$ \\
\hline $\begin{array}{l}\text { Банк может потребовать застраховать имущество, } \\
\text { приобретенное в кредит, но это не обязательно }\end{array}$ & Страхование лизингового имущества обязательно \\
\hline
\end{tabular}

Структура факторингового рынка России по объему бизнеса клиентов за последние годы не претерпела существенных изменений: сделки с крупными клиентами по-прежнему превалируют над сделками в сегменте малого и среднего бизнеса (МСБ). При этом по данным, полученным от факторинговых компаний (финансовых агентов), доля сделок, приходящихся на МСБ, растет и составляет примерно 30 \%. Это связано со снижением информационной прозрачности ряда крупных участников рынка [Корнилович, 2016].

По базовому прогнозу RAEX, рост рынка факторинга в ближайшие годы составит около 7 \%. Данный прогноз предполагает инфляцию на уровне 5-6 \%. В результате лидеры рынка продолжат удешевлять фондирование и будут предлагать клиентам еще более привлекательные условия. Рост рынка факторинга в таких условиях составит около 14 \%, а совокупный объем уступленных денежных требований достигнет порядка 2,4 трлн руб. [Зинина, Тетерин, 2017]. 
На сегодняшний день законодательство предусматривает четыре основных вида страхования:

- личное - страхуются имущественные интересы, связанные с личностью: жизнь, здоровье, трудоспособность;

- имущественное - направлено на защиту имущественных интересов личности. Страховые случаи - повреждение или утрата имущества;

- страхование ответственности - применяется в сферах, где профессиональная ошибка может причинить значительный ущерб: в медицине, среди перевозчиков, бизнесменов; рисков.

- страхование предпринимательского риска - страхование бизнеса и связанных с ним

Основным драйвером роста страхового рынка в России последние четыре года является инвестиционное страхование жизни (ИСЖ). Этот продукт, сочетающий в себе страхование жизни клиента и финансовый инструмент, позволяет получить доход. Суть такого страхования заключается в том, что часть внесенных денег инвестируется в различные финансовые активы, предлагаемые страховщиком (облигации или акции компаний, драгоценные металлы).

Еще одним драйвером может стать ипотечное страхование на фоне стремительного роста объемов ипотечного кредитования населения. Важная причина развития страховых услуг в этом направлении - банкротство застройщиков, реорганизации, слияния и поглощения в строительной отрасли. [Бузин и др., 2019] Банкротство строительных компаний и рост числа обманутых дольщиков, в свою очередь, стали основанием для введения запрета на долевое строительство. В связи с этим страховые услуги могут развиваться в двух направлениях: страхование населения и страхование строительных проектов от банкротства девелопера или застройщика.

Усилится развитие страхования партнерских продуктов с банками, ритейлерами, онлайн-партнерами. В данном сегменте в среднесрочной перспективе возрастет популярность страхования киберрисков клиентов.

Достаточно проблемным направлением в страховании является рынок ОСАГО. Страхование ОСАГО стало невыгодным, зачастую убыточным [Шестакова, Яворская, 2018].

Объем средств населения в банках по состоянию на 1 июля 2019 г. составил 28 982,5 млрд руб.

Средний размер вкладов физических лиц (исключая счета до 1 тыс. руб.) на 1 июля 2019 г. составил 174 тыс. руб., увеличившись с начала года на 4,9 \%.

Средний размер вкладов малых предприятий (исключая счета до 1 тыс. руб.) на 1 июля 2019 г. составил 1332 тыс. руб.

Средние процентные ставки по рублевым годовым вкладам в размере 1 млн руб. остались на прежнем уровне, составив 7,1\%. При этом средний уровень ставок (взвешенных по объему вкладов) по аналогичным вкладам уменьшился с начала года на 0,6 п. п. до 6,5 \% годовых ${ }^{2}$.

Посредническая инвестиционная деятельность коммерческих банков ограничена следующими факторами:

- сохраняющиеся высокие финансовые риски в реальном секторе экономики (низкая рентабельность, значительная долговая и налоговая нагрузка);

- довольно высокий уровень политических рисков;

- рост числа мошеннических действий в кредитном секторе;

- низкий уровень квалификации банковского персонала.

В силу перечисленных факторов деятельность национальных коммерческих банков в качестве посредников (и консультантов) различных инвестиционных проектов пока недостаточно эффективна.

2 По данным Государственной корпорации «Агентство по страхованию вкладов» (www.asv.org.ru). 
В последнее время в связи с ограничительными мерами со стороны зарубежных финансовых институтов остро встал вопрос об обеспечении независимости российской банковской системы. Одним из инструментов ее обеспечения была призвана стать национальная платежная система. [Борисова и др., 2015] С 1 июля 2018 г. все государственные служащие получают выплаты за счет бюджетных средств только с использованием платежной системы «Мир», которая является национальным платежным инструментом.

Причинами разработки национальной платежной системы стали:

1) возможность отключения России от телекоммуникационной системы SWIFT (СВИФТ), используемой при межбанковских расчетах по всему миру;

2) угроза со стороны западных стран ограничить объемы трансакций через популярные международные платежные системы;

3) опасность утечки информации и ограничения финансирования секретных финансовых операций России за рубежом;

4) возросшие требования к защите информации в рамках операций, проводимых через платежные системы.

5) перспективностью национальной валюты стать региональной резервной валютой на постсоветском пространстве и в рамках региональных экономических объединений.

На эффективность финансового сектора экономики страны существенное влияние оказывают правоохранительные органы путем противодействия преступности в финансовом секторе экономики страны [Ивличев и др., 2018]. В таблице 3 представлены данные по выявленным преступлениям в данной сфере без учета составов, предусмотренных ст. 159 УК РФ и 186 УК.

Таблица 3

Table 3

Динамика преступлений в финансовой сфере за 9 месяцев 2020 года по отдельным субъектам РФ

Dynamics of crimes in the financial sphere for 9 months of 2020 by individual subjects of the Russian Federation

\begin{tabular}{|c|c|c|c|c|}
\hline \multirow{3}{*}{$\begin{array}{c}\text { Результаты подразделений ЭБиПК на } \\
\text { приоритетных направлениях оперативно- } \\
\text { служебной деятельности, } \\
\text { январь-сентябрь } 2020 \text { года }\end{array}$} & \multirow{3}{*}{ Штат } & \multicolumn{3}{|c|}{ Финансово-кредитная система } \\
\hline & & \multirow{2}{*}{ Всего } & \multicolumn{2}{|c|}{ Ранг с учетом штата } \\
\hline & & & ЦФО & Россия \\
\hline 1 & 2 & 3 & 4 & 5 \\
\hline Белгородская обл. & 160 & 29 & 18 & 76 \\
\hline Брянская обл. & 161 & 74 & 16 & 51 \\
\hline Владимирская обл. & 157 & 112 & 10 & 27 \\
\hline Воронежская обл. & 249 & 229 & 7 & 18 \\
\hline Ивановская обл. & 130 & 141 & 6 & 16 \\
\hline Калужская обл. & 157 & 90 & 14 & 42 \\
\hline Костромская обл. & 80 & 93 & 3 & 11 \\
\hline Курская обл. & 153 & 82 & 15 & 44 \\
\hline Липецкая обл. & 137 & 113 & 8 & 20 \\
\hline г. Москва & 1374 & 5367 & 1 & 1 \\
\hline
\end{tabular}


Окончание табл. 3

\begin{tabular}{|c|c|c|c|c|}
\hline 1 & 2 & 3 & 4 & 5 \\
\hline Московская обл. & 726 & 1250 & 2 & 3 \\
\hline Р. Дагестан & 242 & 157 & & 31 \\
\hline Рязанская обл. & 139 & 83 & 13 & 36 \\
\hline Кабардино-Балкарская Респ. & 102 & 39 & & 54 \\
\hline Карачаево-Черкесская Респ. & 84 & 19 & & 71 \\
\hline Ставропольский край & 435 & 200 & & 40 \\
\hline
\end{tabular}

Согласно представленным данным наибольшее количество преступлений выявляется в следующих субъектах РФ: г. Москва (5367 ед. - 1 место); Московская область (1250 ед. 3 место). Наименьшее количество преступлений выявлено в Белгородской области (29 ед. 76 место); Карачаево-Черкесской Республики (19 ед. - 71 место).

\section{Заключение}

Таким образом, по результатам исследования нами могут быть сделаны следующие выводы:

Bo-nервых, национальная банковская система РФ развивается умеренными темпами, однако реальный сектор экономики требует активизации механизма кредитования на выгодных рыночных условиях, повышения эффективности активных банковских операций, повышения гибкости национальной платежной системы.

Bo-вmopыx, развитие банковской системы должно сопровождаться совершенствованием национальной платежной системы; повышением эффективности денежно-кредитной политики; повышением качества предоставляемых финансовых услуг в сфере страхования, факторинга и лизинга; развитием финансовой инфраструктуры.

$B$-третьих, эффективность финансового сектора может быть увеличена за счет реализации в полном объеме задач, представленных в Стратегии повышения финансовой доступности в Российской Федерации.

$B$-четвертых, нынешнее положение в финансовом секторе связано как с низкой эффективностью финансовой сферы, так и с сохранением энергосырьевой направленности экспорта, на развитие финансового сектора оказывает влияние ряд факторов, прежде всего это низкая защищенность кредиторов в сфере микрофинансового кредитования, значительный рост мошенничеств в кредитно-финансовой сфере, значительный разрыв в процентных ставках по депозитам и кредитным продуктам, медленное развитие цифровизации финансового рынка и недоверия к рынку ценных бумаг клиентов, создание искусственных барьеров для развития механизма венчурного софинансирования проектов на финансовых площадках. [Lipinsky et. al., 2019]

$B$-nяmblx, развитие финансового сектора должно иметь не одностороннюю направленность в обслуживании только экспортоориентированной модели развития экономки, а отвечать интересам сбалансированного развития всех отраслей реального сектора экономики страны.

\section{Список литературы}

1. Авдийский В.И. и др. 2015. Финансово-экономическая безопасность экономических агентов. Финансы: теория и практика. 5 (89): 40-50.

2. Борисова И.Ю. и др. 2015. Российская экономика под гнетом санкций и дешевой нефти. Вопросы экономики. 7: 5-35.

3. Бузин Р.В., Золотарев И.И., Золотарева Н.А. 2019. Формирование новой мировой экономики в контексте угроз экономической безопасности России. Вестник Воронежского государственного аграрного университета. 12 (4): 235-243. 
4. Гаджиев Н.Г. 2019. Экономическая безопасность: пособие для слушателей, обучающихся на курсах повышения квалификация по направлению «Экономическая безопасность». Н.Г. Гаджиев, С.А. Коноваленко, Г.С. Султанов; под ред. Н.Г. Гаджиева. Махачкала: Изд-во ДГУ. 47.

5. Долбилов А.В., Лошаков А.С. 2017. Обострение угроз экономической безопасности государства в условиях санкционного противостояния. Экономика и управление: проблемы, решения. 2 (1): $24-27$.

6. Зинина М., Тетерин В. 2017. Факторинг оттаял. БДМ. Банки и деловой мир. 5. 63.

7. Ивличев П.С. и др. 2018. Методические аспекты выявления и документирования правонарушений с бюджетными средствами в системе финансового контроля. Экономика и предпринимательство. 11: 1144-1149.

8. Коноваленко С.А. и др. 2019. Зарубежный опыт выявления финансовых правонарушений в государственном секторе экономики. Экономика и предпринимательство. 1: 217-219.

9. Коноваленко С.А., Трофимов М.Н. 2019. Формирование системы показателей обеспечения экономической безопасности в бюджетной сфере. Роль бухгалтерского учета, контроля и аудита в обеспечении экономической безопасности России: 97-103.

10. Корнилович Р.А. 2016. Признаки экономических правонарушений, выявляемые при исследовании бухгалтерских документов правоохранительными органами в кредитной сфере. Финансовая политика государства: современные тенденции и перспективы: сб. мат. Всерос. науч.практ. конф. с междунар. участием: 53-67.

11. Костыря Ю.С., Трофимов М.Н. 2012. Инвестиции как фактор экономической безопасности государства. Вестник Московского университета МВД России. 4: 248-250.

12. Моторина А.А. 2017. Значение нефтегазовых доходов бюджета для формирования резервного фонда и фонда национального благосостояния. Финансовое право. 2: 31-35.

13. Самиев П. 2018. МСБ в лизинг. Банковское обозрение. 6: 93.

14. Седова Ю.В. 2016. Механизм трансформации сбережений в инвестиции. Российское предпринимательство. 17 (4): 555-572. DOI 10.18334/rp. 17.3.34927.

15. Чайка А.А. 2015. Современные угрозы финансовой безопасности России и способы их устранения. Достижения вузовской науки. 16: 169-173.

16. Шестакова Е., Яворская А. 2018. Новые виды страхования. Как будет развиваться рынок страховых услуг. Финансовая газета. 5: 5.

17. Экономическая безопасность: учебник. Под общ. ред. С.А. Коноваленко. Москва: ИНФРА-М, 2021. 526. DOI 10.12737/1048684.

18. Lipinsky D.A., Makareiko N.V., Musatkina A.A. 2019. Legal aspects of ensuring economic security in the conditions of the digital economy development. Amazonia Investiga, 8 (20): 568-574.

19. Reutov V.E. et al. 2019. Methodology for assessing the financial and economic security of the agroindustrial complex. International Journal of Recent Technology and Engineering, 8 (2): 4430-4435.

20. Vivchar O.I. 2016. Management system interpreting financial and economic security business in economic processes International Electronic Journal of Mathematics Education, 11 (4): 947-959.

\section{References}

1. Avdiyskiy V.I. i dr. 2015. Finansovo-ekonomicheskaya bezopasnost' ekonomicheskikh agentov [Financial and economic security of economic agents]. Finansy: teoriya i praktika. 5 (89): 40-50. (in Russian)

2. Borisova I.Yu. i dr. 2015. Rossiyskaya ekonomika pod gnetom sanktsiy i deshevoy nefti [The Russian economy is under the yoke of sanctions and cheap oil]. Voprosy ekonomiki. 7: 5-35. (in Russian)

3. Buzin R.V., Zolotarev I.I., Zolotareva N.A. 2019. Formirovanie novoy mirovoy ekonomiki v kontekste ugroz ekonomicheskoy bezopasnosti Rossii [Formation of a New World Economy in the Context of Threats to Russia's Economic Security]. Vestnik Voronezhskogo gosudarstvennogo agrarnogo universiteta. 12 (4): 235-243. (in Russian)

4. Gadzhiev N.G. 2019. Ekonomicheskaya bezopasnost': posobie dlya slushateley, obuchayushchikhsya na kursakh povysheniya kvalifikatsiya po napravleniyu «Ekonomicheskaya bezopasnost'» [Economic security: a guide for students studying at advanced training courses in the direction of "Economic Security»]. N.G. Gadzhiev, S.A. Konovalenko, G.S. Sultanov; pod red. N.G. Gadzhieva. Makhachkala: Izdvo DGU. 47 s. (in Russian) 
5. Dolbilov A.V., Loshakov A.S. 2017. Obostrenie ugroz ekonomicheskoy bezopasnosti gosudarstva $\mathrm{v}$ usloviyakh sanktsionnogo protivostoyaniya [Aggravation of threats to the economic security of the state in the context of the sanctions standoff]. Ekonomika i upravlenie: problemy, resheniya. 2 (1): 24-27. (in Russian)

6. Zinina M., Teterin V. 2017. Faktoring ottayal [Factoring has thawed out]. BDM. Banki i delovoy mir. 5. 63. (in Russian)

7. Ivlichev P.S. i dr. 2018. Metodicheskie aspekty vyyavleniya i dokumentirovaniya pravonarusheniy $\mathrm{s}$ byudzhetnymi sredstvami $\mathrm{v}$ sisteme finansovogo kontrolya [Methodological aspects of identifying and documenting violations with budget funds in the financial control system]. Ekonomika i predprinimatel'stvo. 11: 1144-1149. (in Russian)

8. Konovalenko S.A. i dr. 2019. Zarubezhnyy opyt vyyavleniya finansovykh pravonarusheniy v gosudarstvennom sektore ekonomiki [Foreign experience in detecting financial offenses in the public sector of the economy]. Ekonomika i predprinimatel'stvo. 1: 217-219. (in Russian)

9. Konovalenko S.A., Trofimov M.N. 2019. Formirovanie sistemy pokazateley obespecheniya ekonomicheskoy bezopasnosti $\mathrm{v}$ byudzhetnoy sfere [Formation of a system of indicators for ensuring economic security in the public sector]. Rol' bukhgalterskogo ucheta, kontrolya i audita $\mathrm{v}$ obespechenii ekonomicheskoy bezopasnosti Rossii: 97-103. (in Russian)

10. Kornilovich R.A. 2016. Priznaki ekonomicheskikh pravonarusheniy, vyyavlyaemye pri issledovanii bukhgalterskikh dokumentov pravookhranitel'nymi organami $\mathrm{v}$ kreditnoy sfere [Signs of economic offenses identified in the study of accounting documents by law enforcement agencies in the credit sector]. R.A. Kornilovich, S.A. Konovalenko. Finansovaya politika gosudarstva: sovremennye tendentsii i perspektivy: sb. mat. Vseros. nauch.-prakt. konf. s mezhdunar. uchastiem: 53-67. (in Russian)

11. Kostyrya Yu.S., Trofimov M.N. 2012. Investitsii kak faktor ekonomicheskoy bezopasnosti gosudarstva [Investment as a factor of economic security of the state]. Vestnik Moskovskogo universiteta MVD Rossii. 4: 248-250. (in Russian)

12. Motorina A.A. 2017. Znachenie neftegazovykh dokhodov byudzheta dlya formirovaniya rezervnogo fonda i fonda natsional'nogo blagosostoyaniya [The importance of oil and gas budget revenues for the formation of the Reserve Fund and the National Welfare Fund]. Finansovoe pravo. 2: 31-35. (in Russian)

13. Samiev P. 2018. MSB v lizing [Small and medium-sized businesses on lease]. Bankovskoe obozrenie. 6: 93. (in Russian)

14. Sedova Yu.V. 2016. Mekhanizm transformatsii sberezheniy v investitsii [The mechanism of transformation of savings into investments]. Rossiyskoe predprinimatel'stvo. 17 (4): 555-572. DOI 10.18334/rp. 17.3.34927. (in Russian)

15. Chayka A.A. 2015. Sovremennye ugrozy finansovoy bezopasnosti Rossii i sposoby ikh ustraneniya [Modern threats to Russia's Financial Security and ways to eliminate them]. Dostizheniya vuzovskoy nauki. 16: 169-173. (in Russian)

16. Shestakova E., Yavorskaya A. 2018. Novye vidy strakhovaniya. Kak budet razvivat'sya rynok strakhovykh uslug [New types of insurance. How will the insurance market develop?]. Finansovaya gazeta. 5: 5. (in Russian)

17. Ekonomicheskaya bezopasnost' [Economic security]: uchebnik. Pod obshch. red. S.A. Konovalenko. Moskva: INFRA-M, 2021. 526. DOI 10.12737/1048684. (in Russian).

18. Lipinsky D.A., Makareiko N.V., Musatkina A.A. 2019. Legal aspects of ensuring economic security in the conditions of the digital economy development. Amazonia Investiga, 8 (20): 568-574.

19. Reutov V.E. et al. 2019. Methodology for assessing the financial and economic security of the agroindustrial complex. International Journal of Recent Technology and Engineering, 8 (2): 4430-4435.

20. Vivchar O.I. 2016. Management system interpreting financial and economic security business in economic processes International Electronic Journal of Mathematics Education, 11 (4): 947-959.

\section{ИНФОРМАЦИЯ ОБ АВТОРАХ}

Трофимов Михаил Николаевич, кандидат экономических наук, старший преподаватель кафедры экономической безопасности Рязанского филиала Московского университета МВД России имени В.Я. Кикотя, г. Рязань, Россия

\section{INFORMATION ABOUT THE AUTHORS}

Mikhail N. Trofimov, Candidate of Economic Sciences, Senior Lecturer of the Department of Economic Security, Ryazan branch of Moscow University of the MIA of Russia named after V.J. Kikot, Ryazan, Russia 
Коноваленко Сергей Александрович, кандидат экономических наук, доцент, профессор кафедры экономической безопасности Рязанского филиала Московского университета МВД России имени В.Я. Кикотя, г. Рязань, Россия

Корнилович Руслан Александрович, кандидат технических наук, доцент, начальник кафедры экономической безопасности Рязанского филиала Московского университета МВД России имени В.Я. Кикотя, г. Рязань, Россия

Гаджиев Назирхан Гаджиевич, доктор экономических наук, проректор по экономике и финансам, заведующий кафедрой аудита и экономического анализа Дагестанского государственного университета, г. Махачкала, Россия
Sergey A. Konovalenko, Candidate of Economic Sciences, Associate Professor, Professor of the Department of Economic Security, Ryazan branch of Moscow University of the MIA of Russia named after V.J. Kikot, Ryazan, Russia

Ruslan A. Kornilovich, Candidate of Technical Sciences, Associate Professor, Head of the Department of Economic Security, Ryazan branch of Moscow University of the MIA of Russia named after V.J. Kikot, Ryazan, Russia

Nasirkhan G. Gadzhiev, Doctor of Economic Sciences, Vice-rector for Economy and Finances, Head of the Department of Audit and Economic Analysis, Dagestan State University, Makhachkala, Russia 